\title{
Seismic and Tectonic Correspondence of Major Earthquake Regions in Southern Ghana with Mid-Atlantic Transform-Fracture Zones*
}

\author{
Jacob M. Kutu \\ Department of Geology, University of Ghana, Accra, Ghana \\ Email: jkutu@ug.edu.gh, kutujm@yahoo.com
}

Received September 14, 2013; revised October 15, 2013; accepted November 12, 2013

Copyright (C) 2013 Jacob M. Kutu. This is an open access article distributed under the Creative Commons Attribution License, which permits unrestricted use, distribution, and reproduction in any medium, provided the original work is properly cited. In accordance of the Creative Commons Attribution License all Copyrights (C) 2013 are reserved for SCIRP and the owner of the intellectual property Jacob M. Kutu. All Copyright (C) 2013 are guarded by law and by SCIRP as a guardian.

\begin{abstract}
For four centuries now, southern Ghana has been known to be seismically active, and there is no clear geological explanation for the cause of the seismicity. By evaluating new field data and information with re-interpreted historical earthquake data of southern Ghana, the nature of the seismicity of southern Ghana has been elucidated. The mutual connection between the earthquake epicentres and the remote causes by Mid-Atlantic transform faults and fracture zones has been established. The seismic regions of southern Ghana have been linked separately to tectonic faults and activities of the St. Paul's and Romanche transform-fracture zone systems offshore in the Gulf of Guinea to onshore. It is concluded that the seismicity of southern Ghana is due to tectonic activities of the St. Paul's and Romanche transform-fracture systems. The Accra region earthquakes originate from reactivation of faults in the Romanche transform-fracture zone, and propagate onshore through Accra and environs. The Axim region earthquakes come from reactivated faults linked to the St Paul's fracture zone, which go through southern Cote D'Ivoire to Ghana. Seismotectonic movements along the St Paul's transform and fracture zones have quieted since 1879. But movement along the Romanche Transform fault and Fracture zone is active, causing ongoing seismicity of southern Ghana.
\end{abstract}

Keywords: Fault System; St Paul's and Romanche Fracture Zones; Southern Ghana; Tectonic Earthquake

\section{Introduction}

Earthquakes are natural crustal stabilization phenomena caused by lithospheric faulting and adjustments that help maintain the crustal stability and spheroidal structure of the Earth. Southern Ghana in West Africa is far away from any major present-day tectonic inter-plate boundaries, active tectonoseismic or volcanogenic regions of the world, yet for centuries the region is seismically active. A number of significant earthquakes have struck southern Ghana and West Africa in the past, some with destructive effects [1-7]. Seismic activities, including major and minor ones, have been going on quite regularly over the centuries to the present [7]. Previous recorded damaging and destructive earthquakes had been reported in places wide apart in southern Ghana, notably from the southwest in the districts of Axim and Elmina to the

*This paper is dedicated to Norman Ross Junner. southeast in the Accra through to the Ho districts [4,6,7].

Recent seismicity in southern Ghana has heightened the need to find explanation for the causes of the earthquake activities in Ghana. Until now, there is no clear geological explanation for the previous and current ongoing seismicity of the Accra region and southern Ghana. Most of the discussions in the literature of the seismicity of Ghana have focused predominantly on earthquakes of the Accra-Ho seismic region at southeastern Ghana, and seem to generalize that for the whole country [e.g. 6-8], inherently suggesting a common cause for the seismicity of the entire southern Ghana. This generalization oversimplifies the nature and understanding of the phenomenon in Ghana.

The objectives of this paper are to establish and explain the nature and causes of the earthquake phenomenon and seismicity of southern Ghana, and then differentiate and correlate seismic activities in southern Ghana to 
causative tectonic fault systems.

\section{Methods}

The study gathered and evaluated new tectonic and geological information from the field, and reassessed historical record of seismic activities and data in southern Ghana. Re-interpretation based on new tectonic and structural data and information on the local and regional geology of the region was done, using also the re-interpreted data of the well documented 1939 Accra Earthquake. Field work results on the geology and tectonics were used with existing 1939 Earthquake parameters in constraining baseline characteristics and causes of the seismicity of the region. My hypothesis is that the epicentres of earthquakes in Ghana are located both onshore along the coastal regions of Ghana and her neighbouring countries and offshore in the Gulf of Guinea, hence, the causative forces and faults must be acting from that whole region. Major faults in southern Ghana were traced offshore and vice versa onshore. Historical earthquake events were correlated with the transform and fracture zones to deduce the zones of seismic activity and the tectonic relations.

\section{Geological Setting}

Figure 1 shows the study area of southern Ghana as part of continental West Africa in the equatorial Atlantic setting of Mid-Atlantic ridge and transform-fracture systems. Geologically, Ghana consists of the Proterozoic Birimian province of the West African Craton, at its west part, and the Dahomeyide Orogen at the southeast of mainland Ghana, both partially covered by the Neoproterozoic Voltaian cover sequence [1,9-12]. These two terranes are separated by a major NE-SW tectonic boundary, along which the Dahomeyide Orogen with its metasedimentary Akwapimian cover sequence is thrust westward onto the eastern margin of the West African Craton. The boundary zone is characterized by three boundaryparallel tectonic units, namely, the eastern margin of the crystalline Birimian crust as the western block, the narrow middle meta-sedimentary Akwapimian block, and the external crystalline granulite Dahomeyide terrane block to the east, all separated by clear lithotectonic boundaries $[1,9,10,13,14]$.

Offshore in the Atlantic Gulf of Guinea, three main WSW-ENE trending structures are recognized, namely, St. Paul's, Romanche and Chain transform faults and fracture zones (Figure 1; [15]), which are stable tectonic flow lines [16].

A transform fault is an active tectonic intra-plate boundary where a fault or set of parallel strike-slip faults has cut across a mid-ocean ridge and offset the ridge during seafloor spreading, in which tectonic plate fault-bounda-

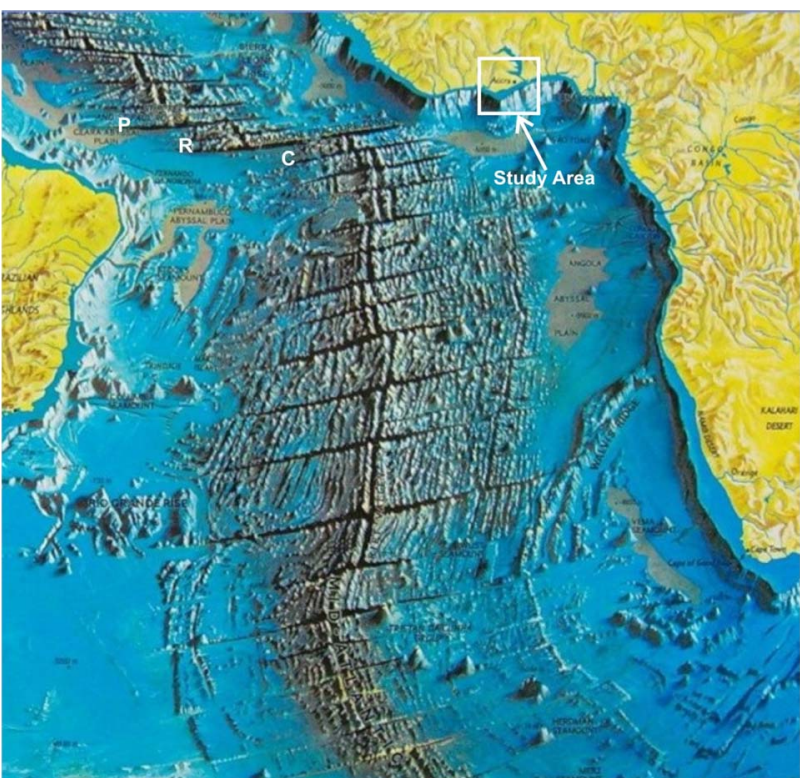

Figure 1. Showing Google Earth satellite image of the Study Area in southern Ghana (West Africa), the mid-Atlantic Ridge and its transform faults and fracture systems, including St. Paul's (P), Romanche (R) and Chain (C) transform faults and fracture zones (Modified after Source: [15]).

ries slide past each other in opposite direction and uniquely define the direction and sense of motion between offset ridges of two bounding plates [17]. According to Condie (1997) [17], there are three types of transform faults: the ridge-ridge, ridge-trench, and trench-trench types. The ridge-ridge type is most common globally, and such types tend to maintain their length constant over time. The other two types decrease or increase their length as they evolve. The St. Paul's, Romanche and Chain transform faults are the ridge-ridge type. Transform faults may evolve and develop extensions beyond the zone of the offset ridges, where they produce large structural discontinuities in the seafloor crust and topographic breaks and highs known as "fracture zones" [17]. The fracture zones mark locations of progressed extensions of transform faults, where plate boundaries move in the same direction. Fracture zones occur across and often extend away from transform faults or mid-ocean ridges usually towards continents (Figure 1) or tectonic trenches. A fracture zone, therefore, is an elongate zone of prominent irregular topographic faults, breaks or mountain range that cuts across the ocean floor and major features thereon, and separates regions of different crustal depths developed during the construction and migration of the crust in seafloor spreading. A typical fracture zone is about 60 kilometres wide and several hundred kilometres long, and is characterized by high-angle strike-slip faults [18]. Series of such ridge-ridge type transform faults and fracture zones characterize the Atlantic seafloor of West Africa and Ghana, where they form straight to arcuate 
lineaments from the Mid-Atlantic Ridge to the African continent (Figure 1). The Ghana part of this region is influenced in its evolution by the St. Paul's, Romanche and Chain transforms and fracture zones (Figure 1). The Romanche Transform and Fracture Zone and two boundary fault-splays are known to reach onshore Ghana [11, 19]. The question is: "What is the cause and nature of the seismicity of southern Ghana?"

\section{Results}

The results of the study, presented in Tables $\mathbf{1}$ and $\mathbf{2}$ and Figures 2-6, show that the ridge-ridge type transform faults and fracture zones of the Atlantic seafloor of West Africa reach Ghana and play a major role in earthquake activity in Ghana and West Africa. Table 1 outlines the major earthquakes so far experienced in Ghana, their locations, maximum intensities and magnitudes. In 1636 a strong magnitude 5.7 earthquake hit Axim. But before then in 1615, Elmina had experienced the first documented earthquake in Ghana [4]. In 1862 and1872 major earthquakes hit the same Accra region. In 1906 a magnitude 6.2 earthquake struck Ho and Accra. Another major earthquake struck Accra on $22^{\text {nd }}$ June 1939 , some 74 years ago, and became known as the 1939 Accra Earthquake [1]. The Accra events of 1862 and 1939 were the severest reported, and had been assigned maximum seismic intensity IX and magnitude $6.5[1,3,6]$. Table 2 shows key historical earthquake data for only western Ghana and Cote D'Ivoire separately, as basis for comparison with the greater majority at southeastern Ghana.

Over these last 400 years of seismicity, the greater majority of epicentral earthquakes have occurred in southeastern Ghana, none in central mid-belt and northern Ghana, and only a few earthquakes have struck the southwestern part of Ghana and southern Cote D'Ivoire (Tables 1 and 2). And for almost two and half centuries now, since the last major event in Cote D'Ivoire in 1879, the southwestern part of Ghana has been seismically quiet, while the southeast region is active to the present day.

The results in Figure 2, reconstructed from Figure 1, show the present tectonic and structural configuration of the Atlantic crust, Mid-Atlantic Ridge, and the equatorial transform and fractures zones, obtained from tracing of southern Ghana faults into offshore fracture zones and vice versa.
The Romanche transform fault and its zone constitute the most prominent of these tectonic features. It is a typical long ridge-ridge transform offset with a longer fracture zone. The present-day transform offset is roughly 888 kilometres long and the adjoining fracture zone is 1890 kilometres (Figure 2). The main eastern end of the Romanche fracture zone fault reaches onshore near GoiSege some $100 \mathrm{~km}$ east of Accra. Adjacent to the Romanche system is the St. Paul's system to the north, and to the south is the Chain system (Figure 2; [21]). Figure 3 shows the map of the trends and patterns of the St. Paul's and Romanche faults systems, their splays, and cross-cutting relations in southern Ghana. Figure $\mathbf{4}$ shows field evidence of faults traced from sea into the Accra Boundary fault on land, while Figure 5 presents ground evidence of the cross-fault at Kokrobite (Accra Coastal Boundary Fault-ACBF and Akwapimian Fault-AKF), located west of Accra. Two generations of faults, characterized by isoclinal shear fractures over 100 metres wide, cross cut at Kokrobite, the earlier Akwapimian Fault (AKF) having fault plane attitudes ranging from $280 \%$ $90^{\circ}$ to $326^{\circ} / 76^{\circ} \mathrm{E}$, and the later generation Accra Coastal Boundary Fault (ACBF) having fault plane attitudes ranging from $060^{\circ} / 80^{\circ} \mathrm{E}$ to $090^{\circ} / 85^{\circ} \mathrm{E}$ (Figures 4 and 5).

The St. Paul's fracture zone is traced onshore into the Ivory Coast Fault which continues into southwest Ghana and passes north of Axim (Figure 3). In southwest Ghana, the fault has been identified in gravity surveys [10]. This major fault has carved out a large fault-crafted basin south of it just along the Atlantic Gulf of Guinea coast, where the larger portion occurs in Cote d'Ivoire as the Abidjan Basin (Figure 3), and the tapered east end forms the southwest corner of Ghana, referred to as the Apollonian Basin. This constitutes the onshore Tano Basin, with its 3500-metre thick Upper Cretaceous (100 - 65 $\mathrm{Ma})$ marine sedimentary sequence, including the fossiliferous Nauli limestone, which sequence is confirmed by drilling $[10,22]$. The larger basin, which deepens westward into Cote d'Ivoire, was sunken in its formation, and later upthrown; this may explain the onshore formation of the limestone deposit (located some 50 kilometres west of Axim) and the general stratigraphic sequence. Structurally, the shelly limestone formation and the host strata dip generally $2^{\circ}-5^{\circ}$ south to southwest [10]. This basin and the Axim-Elmina region have experienced earthquakes in the past (Table 2).

Table 1. Key Historical Earthquake Data and Time Intervals of Southern Ghana.

\begin{tabular}{|c|c|c|c|c|c|c|c|}
\hline Year & 1615 & 1636 & 1862 & 1872 & 1906 & 1939 & 1969 \\
\hline Intensity & VIII & IX & IX & VII & VIII & IX & VI \\
\hline \multicolumn{2}{|c|}{ Magnitude } & 5.7 (MS) & 6.5 (ML) & 4.9 & 6.2 (ML) & 6.5 (MR) & 4.8 \\
\hline Location & Elmina & Axim & Accra & Accra & Ho-Accra & Accra & Accra \\
\hline Period, Yrs & & 21 & 247 & 10 & 34 & 33 & 30 \\
\hline
\end{tabular}

MS - Surface wave magnitude, ML - local magnitude, MR -Richter scale magnitude, Yrs - period in years. (Data sources: [1-7]. 
Table 2. Key Historical Earthquake Data of western Ghana and Cote D'Ivoire.

\begin{tabular}{|ccccc|}
\hline Year & 1615 & 1636 & 1879 \\
\hline Intensity & VIII & IX & VIII \\
Magnitude & \multicolumn{2}{c|}{5.7 (MS) } & $5.7(\mathrm{ML})$ \\
Location & Elmina & Axim & Abidjan \\
Period, Yrs & & & 21 & 243 \\
\hline
\end{tabular}

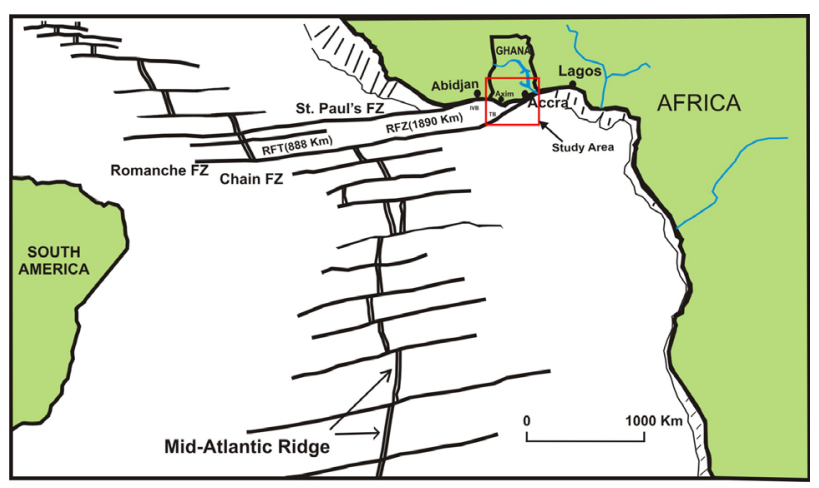

Figure 2. Map showing Western Africa, the mid-Atlantic Ridge and St. Paul's, Romanche and Chain transform faults and fracture zones (Sources: Redrawn after Tout sur Google Earth, 2008, Figure 1 [15]; and Flashearth, 2009 [20]).

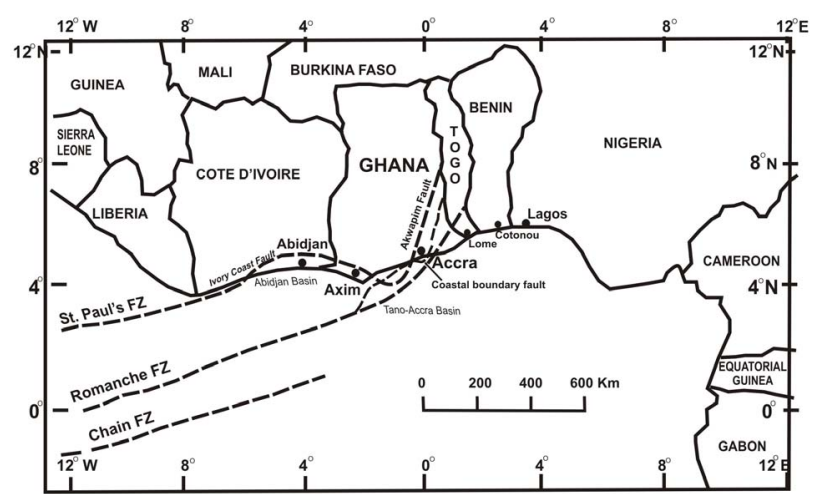

Figure 3. Map of West Africa showing the regional tectonic framework of the St. Paul's, Romanche and Chain transform faults and fracture zones.

Figure 6 is map of southern Ghana showing the composite plot of epicentres of the historical earthquakes in Table 1 in relation to the causative faults linked to Atlantic fracture zones of the St. Paul's and Romanche, respectively, which define two seismic regions, A and B, in Ghana, together with the seismic hazard zones of southern Ghana based on the matching of historical seismic intensities and magnitudes in relation to fracture zone fault.

\section{Discussion}

The earthquakes in Ghana so far were all shallow-focus genetically tectonic earthquakes [1,23-25], caused by re-

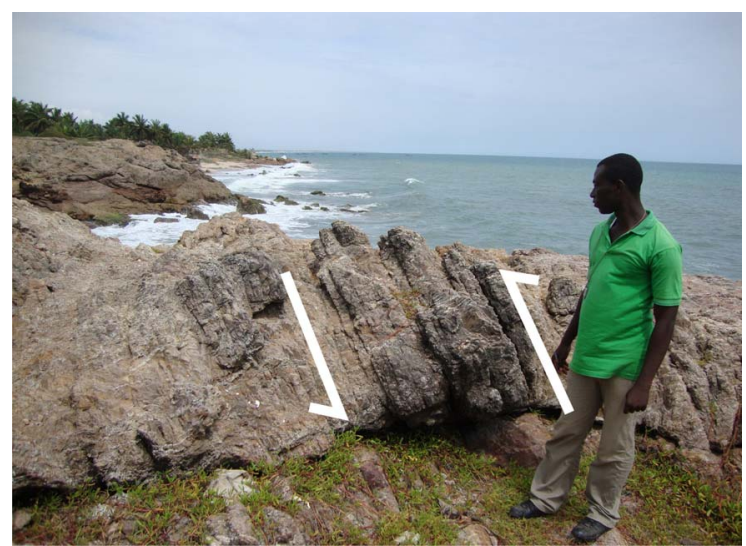

Figure 4. Showing the subveritical sinistral strike-slip Accra Coastal Boundary fault at Kokrobite (Accra West, a splay of the Romanche FZ), in strongly brecciated Akwapimian quartzite; trending east offshore in the Gulf of Guinea (Photo taken facing east).

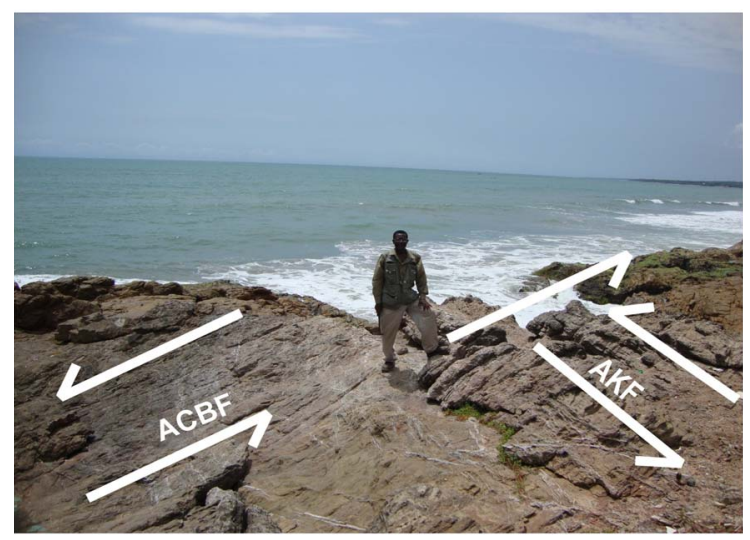

Figure 5. Showing Accra Coastal Boundary Fault (ACBF) trending east parallel to coastline, and the Akwapimian Fault (AKF) trending offshore north-south.

EARTHQUAKE RISK ZONES OF SOUTHERN GHANA

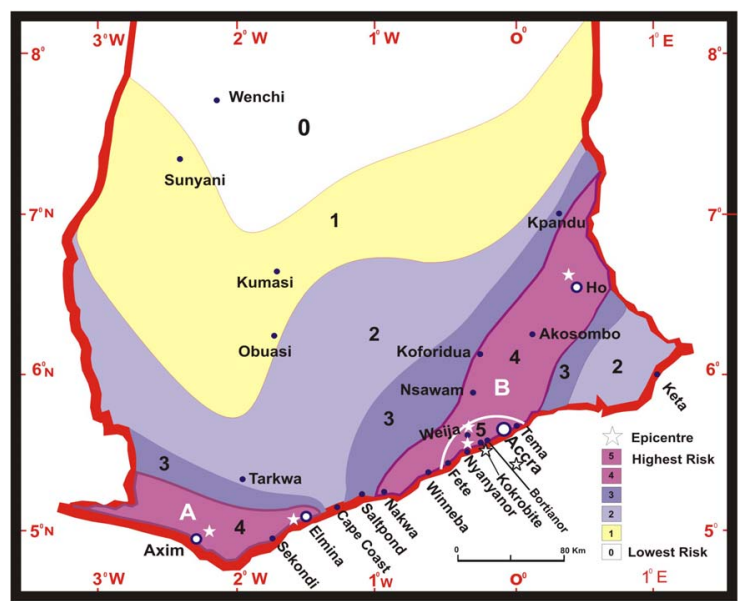

Figure 6. Map showing the Axim-Elmina (A) and Accra- Ho (B) seismic regions, plot of major earthquake epicentres, and the general earthquake risk-level zones of southern Ghana. 
activation of old regional faults. Characteristically, they were accompanied by considerable foreshock and aftershock productivity [1], confirming them as shallow earthquakes [26]. The most representative and well-documented one was the 1939 Accra Earthquake of magnitude 6.5, which had epicentral location $40 \mathrm{~km}$ offshore to the SE of Accra at approximately $5^{\circ} 11^{\prime} \mathrm{N}, 0^{\circ} 8^{\prime} \mathrm{W}$, in the Gulf of Guinea [1]. Its depth of focus was $13.4 \mathrm{~km}$ depth. The causative fault was a high-angle strike-slip NNEtrending fault. Junner et al. (1941) [1] gave the trend of the actual en echelon fissures on the ground between Fete and Weija in the Accra region as $\mathrm{N} 30^{\circ} \mathrm{E}\left(030^{\circ}\right)$ in a general direction that swung between northeast $\left(045^{\circ}\right)$ and $\mathrm{N} 60^{\circ} \mathrm{E}\left(060^{\circ}\right)$ indicates a sinistral subvertical seismic shear faulting of the Accra region, which sense is consistent with the trend and sense of the Equatorial Atlantic transform and fracture zone systems of the St. Paul's and Romanche systems onshore (Figures $\mathbf{2}$ and $\mathbf{3}$ ).

Traced trends and correlation of historical earthquake epicentres with the transform fracture systems revealed patterns of seismic activity, the tectonic relations among them and two distinct seismic regions in Ghana. The results show that the Axim-Elmina earthquakes are due to activity of the St. Paul's transform-fracture zone system, while those of the Accra-Ho region are related mainly to activities of the Romanche transform-fracture zone system (Figure 3). Because the St. Paul's transform-fracture zone system comes onshore through Cote D'Ivoire and swings to the east to intersect the splay of the Romanche entering the Accra seismic region, its activities partially influence seismicity of the Accra region when it activates. This fault system, consisting of splays of the Romanche and the easterly deflection of the St. Paul's systems, has been linked to several historical earthquakes in the Accra region. Subvertical transcurrent or strike-slip faults were linked to tectonic activity along the Atlantic fracture zones, including the Romanche Fracture Zone [11,19]. Fracture zones, especially those elevated, are tectonically active fault zones undergoing displacement [18]. Fracture zones may not be just simple strike-slip faults, but zones of complex network of splays of shear faults [17], hence they are not characterized by large vigorous and frequent seismic activity, but rather intermittent small, medium and large earthquake activities, mostly generated along the transform faults and fracture zones [18,27]. In the coastal region of Ghana, this network system of splays and interfering faults occur, illustrated in Figure 3, where the St. Paul's and Romanche systems form a network and interfere as cross-faults to structurally configure southern Ghana, and cause on-going seismicity of the region. For instance, the Accra-block boundary faults cross-cut one another to form cross-faults west of Accra at Kokrobite (Figures 4 and 5). The south-western region of Ghana is essentially affected by tectonic movements of the St.
Paul's fault system, and not affected by the Romanche and Chain systems.

Though most of the discussions of the seismicity of Ghana in the literature have focussed on events in the Accra-Ho region, and do generalize those for the entire country saying little or nothing about the causes of the seismic activity in the Axim-Elmina area [7,8], the tectonic causes attributed to the seismicity of the Accra-Ho region are different from those for the seismicity of the Axim-Elmina region. The statistics in Table 1, supported by data of Table 2 and Figure 2, reveal a clear time and regional pattern of occurrence; that there are two distinct seismic regions in Ghana, namely, the Axim-Elmina and Accra-Ho regions. From these results it is clear that the seismic activities of the Axim-Elmina and Accra-Ho regions have separate causes. Figure 6 shows the two main seismogenic zones of Ghana as the Axim-Elmina (A) and Accra-Ho (B) regions. The Axim-Elmina region earthquakes come from reactivated faults in the St Paul's transform-fracture zone system offshore in the Gulf of Guinea propagated through Cote D’Ivoire to Ghana. The Accra-Ho region earthquakes come from reactivated faults in the Romanche transform-fracture zone system offshore in the Gulf of Guinea, and propagated onshore through the splays of the Accra Coastal Boundary fault and Akwapimian fault northeastwards. The earthquake shocks of Accra are also felt in Ho, and sometimes in Lome (Figure 3) located just to the southeast of Ghana in the Republic of Togo. Similarly, earthquake shocks of Axim are also felt in Elmina, and most probably Abidjan in Cote D'Ivoire. Generally Cape Coast remains as the stable low seismic zone between these two high seismic regions of southern Ghana (Figure 6).

The nature of the stress patterns affecting the crust of southern Ghana seems to be related to the Atlantic crust tectonic stresses, activities and trends. These stress patterns are mirrored by the distribution of earthquake foci and epicentres. In West Africa the pattern would suggest a NE-SW shear stress configuration in sinistral strike-slip fault geometry. Yarwood and Doser (1990) [28], in evaluating the 1939 Accra Earthquake, used waveform inversion of the teleseismic $\mathrm{P}$ waves to assess the nature of the earthquake. They considered that the earthquake-causing tectonic movement occurred along the Romanche and Chain fracture zones, partly in agreement with the Chain fracture zones argument of Burke [8], and concluded that the event consisted of two shocks: a smaller magnitude 6.1 shock followed 9.5 seconds later by a larger magnitude 6.4 shock. The smaller shock apparently occurred on-land immediately north of the intersection of the Akwapim fault and the Coastal Boundary fault (i.e. cross fault at Kokrobite), and the larger shock seemed to have occurred along a strike-slip fault parallel to the Ghana coast (Accra Coastal Boundary fault). They further indi- 
cated that the waveform inversion results obtained and the trend of the historical earthquakes epicentres (and foci) indicate that not all the tectonic movement along the Romanche and Chain fracture zones is being transmitted inland along the Akwapim fault, but that some of it was deflected tangentially along a fault that is parallel to the NE-trending Ghana coastline [28]. From this study, the Akwapimian and Accra boundary faults are fault splays of the fracture zone system emanating from the St. Paul's and Romanche fracture zones (Figure 3), which splays interact as interference cross faults and serve as boundary faults of the Accra-Ho seismic region.

The seismicity of southern Ghana does not seem to be an isolated series of tectonic events, but rather is a more complex on-going activity involving several fault sets and fault systems, some volcanic activities, and local factors of crustal adjustments and settling. According to Okal and Stewart [27], active submarine volcanism and seamounts are known to occur in the periphery of the Romanche system. The Romanche transform fault and fracture zone are influenced by complex asthenopheric volcanism and activities of emplacement of new oceanic crust materials, especially in the vicinity of the midocean ridge; responsible for lubricating faults, and so smoothing and slowing seismic activities along the transform faults. They mediate the occurrence of slow earthquakes along the active transform fault; and their absence causes occurrence of fast regular earthquakes along the passive more rigid fracture zone. The region of southern Ghana is clearly experiencing movements along the St. Paul's and Romanche fracture zones. The seismic activity is characterized by a fairly wide distribution of multiple-fault focal centres. The faults responsible for the earthquakes may be old or ancient faults, Pan African or at least 65 Ma old formed during the opening of the Equatorial Atlantic oceanic region in the Cretaceous [29], that are only being reactivated by present-day tectonic movements. Clearly, the creation of the onshore Ivory Coast and Tano basins were related tectonically and co-incidentally Cretaceous in age apparently coeval with the opening of the Atlantic mid-ridge and ocean.

Seismotectonic movements along the St. Paul's transform and fracture system have quieted significantly over the last thirteen decades (Table 2); but movement is quite active even in the present-day along the Romanche Transform fault and Fracture zone, causing ongoing seismicity of southern Ghana in the Accra-Ho region. Thus the seismic activity of southern Ghana emanates from a system of Atlantic fracture zones dominated by the Romanche and St. Paul's fracture zones and their splays. Two seismogenic regions of Ghana are recognized: Axim-Elmina seismic and Accra-Ho seismic regions. Of these two, the Axim-Elmina region, influenced by the St. Paul's transform and fracture system, has quieted over the last 130 years. The Accra region remains seismically active and the causative forces are responsible for most of the past and current seismicity of Ghana. The Accra-Tema corridor of the Accra-Ho seismic region is the most active and most hazardous earthquake zone in Ghana.

\section{Conclusion}

Earthquakes and seismicity of southern Ghana are genetically tectonic, caused by reactivation of old, high crust, regional oceanic-continental faults. They are shallow earthquakes related to sinistral subvertical strike-slip faults. The seismicity of southern Ghana emanates from fault systems of the Atlantic fracture zones dominated by the Romanche and St. Paul's fracture zones. The creation of the Ivory Coast-Tano basins and the opening of the Atlantic mid-ridge and ocean both occurred in the Cretaceous and were most likely tectonically related to the seismic fault systems. Two seismogenic regions of Ghana are recognized, as the Axim-Elmina seismic and Accra-Ho seismic regions. The Accra-Ho region earthquakes come mainly from reactivated faults in the Romanche fracture zone with some influence from the St. Paul's fracture zone system. The Axim-Elmina region earthquakes come from reactivated faults in the St Paul's fracture zone system offshore in the Gulf of Guinea through Cote D'Ivoire into Ghana. Seismotectonic movements along the St Paul's transform and fracture zones have quieted significantly in the last century; but movement is taking place even in the present day along the Romanche transform-fracture zone system, causing ongoing seismicity of southern Ghana. The Accra-Ho region remains seismically active and the causative forces are responsible for most of the past and current seismicity of Ghana. The Accra-Tema corridor of the Accra-Ho seismic region is the most active and most susceptible earthquake area in Ghana.

\section{Acknowledgements}

Funds and support for this research came from the University of Ghana "Book \& Research Allowance Facility" and Geodita Consult. Author is grateful to the Ghana Geological Survey for permitting use of the historical earthquake data in this work. The paper benefited from several suggestions made by geoscientist Dr. Chris Anani.

\section{REFERENCES}

[1] N. R. Junner, D. A. Bates, E. Tillotson and C. S. Deakin, “The Accra Earthquake of $22^{\text {nd }}$ June, 1939," Gold Coast Geological Survey Bulletin, No. 13, 1941, pp. 1-57.

[2] Nature 147, "The Accra Earthquake of June 22, 1939," 1941.

http://www.nature.com/nature/journal/v147/n3737/abs/14 
7751a0.html

[3] A. O. Quaah, "Microseismicity, Past Seismic Activity and Seismic Risk in Southern Ghana,” Ph.D. Thesis, University of London, London, 1980.

[4] N. N. Ambraseys and R. D. Adams, "Seismicity of West Africa,” Annales Geophysicae, Vol. 4B, No. 6, 1986, pp. 769-702.

[5] P. E. Amponsah, "Seismic Activity in Relation to Fault Systems in Southern Ghana,” Journal of African Earth Sciences, Vol. 35, No. 2, 2002, pp. 227-234. http://dx.doi.org/10.1016/S0899-5362(02)00100-8

[6] P. E. Amponsah, "Seismic Activity in Ghana: Past, Present and Future," Annals of Geophysics, Vol. 47, No. 2-3, 2004, pp. 539-543.

[7] P. Amponsah, G. Leydecker and R. Muff, "Earthquake Catalogue of Ghana for the Period 1615-2003 with Special Reference to the Tectono-Structural Evolution of South-East Ghana,” Journal of African Earth Sciences, Vol. 75, 2012, pp. 1-13. http://dx.doi.org/10.1016/j.jafrearsci.2012.07.002

[8] K. Burke, "Seismic Areas of the Guinea Coast Where Atlantic Fracture Zones Reach Africa,” Nature, Vol. 222, 1969, pp. 655-657. http://dx.doi.org/10.1038/222655b0

[9] W. J. McCallien, “The Rocks of Accra,” University of Ghana Publ. Board, Legon, 1962.

[10] G. O. Kesse, "The Mineral and Rock Resources of Ghana,” A.A.Balkema Publishers, the Netherlands,1985.

[11] K. Attoh, L. Brown, J. Guo and J. Heanlean, "Seismic Stratigraphic Record of Transpression and Uplift on the Romanche Transform Margin, Offshore Ghana,” Tectonophysics, Vol. 378, No. 1-2, 2004, pp. 1-16. http://dx.doi.org/10.1016/j.tecto.2003.09.026

[12] Ghana Geological Survey and BGR, "Geological Map of Ghana 1:1000000,” Ghana Geological Survey Department, Accra/ Federal Institute for Geosciences and Natural Resources, Hannover, 2009.

[13] W. R. Fitches, "Pan African Orogeny in the Coastal Regions of Ghana,” Nature, Vol. 226, No. 5247, 1970, pp. 744-748. http://dx.doi.org/10.1038/226744a0

[14] K. Attoh, R. D. Dallmeyer and P. Affaton, "Chronology of Nappe Assembly in the Pan-African Dahomeyide Orogen, West Africa: Evidence from ${ }^{40} \mathrm{Ar} /{ }^{39} \mathrm{Ar}$ Mineral Ages," Precambrian Research, Vol. 82, 1997, pp. 153-171. http://dx.doi.org/10.1016/S0301-9268(96)00031-9

[15] Tout sur Google Earth, "Atlas des Mers et des Oceans," image, cinabrio over-blog.es, 2008. http://i66.serving.com/u/f66/11/66/76/31/a_1410.jpg

[16] R. D. Muller and W. R. Roest, "Fracture Zones in the North Atlantic from Combined Geosat and Seasat Data,"
Journal of Geophysical Research, Vol. 97, No. B3, 1992, pp. 3337-3350. http://dx.doi.org/10.1029/91JB02605

[17] K. C. Condie, "Plate Tectonics and Crustal Evolution," 4th Ed., Butterworth-Heinemann, Oxford, 1997.

[18] A. Cox and R. B. Hart, "Plate Tectonics: How It Works," Blackwell Scientific Publications, Inc., Palo Alto, 1986.

[19] D. J. Blundell and J. K. A. Banson, "Interpretation of Seismic Reflection Survey across the Continental Shelf South of Accra and Its Bearing on Earthquakes in the Area," Ghana Geological Survey Report, No. 75/1, 1975, $7 \mathrm{p}$.

[20] Flashearth, “NAVTEQ-Bing Maps,” Microsoft Corporation, Imagery@NASA, 2009. http://www.Flashearth.com/bing maps/msl

[21] X. Le Pichon and D. E. Hayes, "Marginal Offsets, Fractures Zones, and the Early Opening of the South Atlantic,” Journal of Geophysical Research, Vol. 76, No. 26, 1971, pp. 6283-6293. http://dx.doi.org/10.1029/JB076i026p06283

[22] M. H. Khan, "Cretaceous and Tertiary Rocks of Ghana, with Historical Account of Oil Exploration,” Ghana Geological Survey Bulletin, No. 40, 1970.

[23] M. Gary, Jr., R. McAfee and C. L. Wolf, "Glossary of Geology,” American Geological Institute, Washington DC, 1974.

[24] B. A. Bolt, "Earthquakes: A Primer,” W.H. Freeman and Co., San Francisco, 1978.

[25] P. Singh, "Engineering and General Geology,” 8th Edition, S. K. Kataria \& Sons, Delhi, 2008.

[26] D. A. Wiens and H. J. Gilbert, "Effect of Slab Temperature on Deep-Earthquake, Aftershock Productivity and Magnitude-Frequency Relations,” Nature, vol. 384, 1996, pp. 153-156. http://dx.doi.org/10.1038/384153a0

[27] E. A. Okal and L. M. Stewart, "Slow Earthquakes along the Oceanic Fracture Zones: Evidence for Asthenospheric Flow away from Hotspots?” Earth and Planetary Science Letters, Vol. 57, No. 1, 1982, pp. 75-87. http://dx.doi.org/10.1016/0012-821X(82)90174-1

[28] D. R. Yarwood and D. I. Doser, "Deflection of Oceanic Transform Motion at a Continental Margin as Deduced from Waveform Inversion of the 1939 Accra, Ghana Earthquake,” Tectonophysics, Vol. 172, No. 3-4, 1990, pp. 341-349. http://dx.doi.org/10.1016/0040-1951(90)90040-F

[29] M. R. Binks and J. D. Fairhead, "A Plate Tectonic Setting for Mesozoic Rifts of West and Central Africa," Tectonophysics, Vol. 213, No. 1-2, 1992, pp. 141-151. http://dx.doi.org/10.1016/0040-1951(92)90255-5 